\title{
Numerical simulation for optimization of ultra-thin n-type AZO and TiO2 based textured p-type c-Si Heterojunction Solar Cells
}

\section{Chandan Yadav}

National Physical Laboratory CSIR

sushil kumar ( $\sim$ skumar@nplindia.org )

National Physical Laboratory https://orcid.org/0000-0003-2927-1392

\section{Research Article}

Keywords: Heterojunction, HIT solar cells, Texturing angle, Numerical simulation, AFORS-HET

Posted Date: February 23rd, 2021

DOl: https://doi.org/10.21203/rs.3.rs-225454/v1

License: (c) (1) This work is licensed under a Creative Commons Attribution 4.0 International License.

Read Full License 


\section{Abstract}

A maximum efficiency of $17 \%$ for ultra-thin n-type $\mathrm{AZO}$ layer and $17.5 \%$ for ultra-thin $\mathrm{n}$-type $\mathrm{TiO}_{2}$ layer based silicon heterojunction solar cell is reported by optimizing its properties which is much higher than practically obtained efficiency signifying a lot of improvements can be performed to improve efficiency of $\mathrm{TiO}_{2} / \mathrm{Si}$ and $\mathrm{AZO} / \mathrm{Si}$ heterojunction solar cell. AZO layer and $\mathrm{TiO}_{2}$ layer is used as $\mathrm{n}$-type emitter layer and crystalline silicon wafer is used as p-type (p-cSi) layer for modelling $\mathrm{AZO} / \mathrm{Si}$ and $\mathrm{TiO}_{2} / \mathrm{Si}$ heterojunctions solar cell respectively using AFORS HET automat simulation software. Various parameters like thickness of $\mathrm{AZO}, \mathrm{TiO}_{2}$ layer, $\mathrm{p}$-cSi layer, doping concentration of donors $(\mathrm{Nd})$ and effective conduction band density (Nc) are optimized. Finally, texturing at different angle is studied and maximum efficiency is reported at $70 \mu \mathrm{m}$ thick $\mathrm{p}$-type crystalline Silicon ( $\mathrm{p}$-cSi) wafer, that can be very helpful for manufacturing low cost $\mathrm{HJ}$ solar cells at industrial scale because of thin wafer and removal of additional processing setup required for deposition of amorphous silicon i-layer. Utilization of $\mathrm{TiO}_{2}$ and Aluminium doped $\mathrm{Zinc}$ Oxide as n-type layer and p-cSi as p-type layer can help in producing low cost and efficient heterojunction (HJ) than compared to HJ with intrinsic thin layer HIT solar cells.

\section{Introduction}

Demand of energy consumption is tremendously increasing day by day in today's world and to meet the same, contribution from renewable energy sources has to be increased. Conventional non-renewable energy sources are limited and have many environmental concerns. Renewable energy sources are the solution to overcome the problems related to non-renewable energy sources like pollution, limited stock, environmental problems, etc. [1]. In recent times, solar energy is one of most widely commercially used renewable energy source. Photovoltaic solar cell technology is currently dominated by silicon wafer based solar cells by almost $90 \%$ [2]. In recent past, silicon heterojunction solar cells developed by sanyo company based on heterojunction with intrinsic thin layer (HIT) concept is widely used to manufacture solar cells at industrial scale due to their good efficiency, cost effectiveness and economic viability $[3,4]$. Further, numerous research on thin film based silicon heterojunction solar cell is ongoing using metal oxides as n-type layer with crystalline silicon ( $\mathrm{p}$-cSi) wafer as $\mathrm{p}$-type as well as metal oxides as $\mathrm{p}$-type layer with n-type cSi ( $\mathrm{n}$-cSi) wafer due to their easy availability and environment friendly [5-9]. Aluminium doped zinc oxide (AZO) and zinc oxide can be used as window layers, antireflection coating (ARC) layer \& as TCO layer in solar cells $[10,11]$. They also find applications in other devices like transducers, ultrasonic oscillators and gas sensors. $\mathrm{ZnO}$ can be used as a substitute for indium tin oxide (ITO) as it is cheaper than ITO and also enhances the efficiency of solar cells [12]. ZnO can be doped with elements like Al, B, F, $\mathrm{Ga}$, In etc. to make it n-type $\mathrm{ZnO}$. Titanium dioxide $\left(\mathrm{TiO}_{2}\right)$ can also be used as n-type layer which has significant electrical conductivity and high visible transparency [13]. $\mathrm{TiO}_{2}$ can be doped to make further $\mathrm{n}$ type or p-type material, where it can be doped with $\mathrm{Cr}^{3+}, \mathrm{Fe}^{3+}, \mathrm{Ni}^{+2}$ and $\mathrm{Co}^{+2}$ to make $\mathrm{p}$-type and elements like $\mathrm{Sn}, \mathrm{N}, \mathrm{Al}, \mathrm{F}$ etc. to make n-type $\mathrm{TiO}_{2}$. $\mathrm{TiO}_{2}$ can be fabricated using physical and chemical deposition techniques. Some vaccum based techniques like sputtering, pulsed laser deposition (PLD), chemical vapour deposition (CVD) and some solution based techniques like sol-gel, dip/spin coating, and spray 
pyrolysis can be used for deposition of $\mathrm{TiO}_{2}$ films. Vaccum based technology is used for fabrication of solid state device, although this technology is more expensive than solution based technology. Sputtering method is suitable for uniform coating on substrate with large area. It has been established as standard technique for deposition of transparent semiconducting oxide films. Pulsed laser deposition (PLD) technique is used for deposition of robust and nanostructured thin films. This technique is very efficient technique which is capable to assist laser desorption and ionization of low molecular weight. Chemical vapour deposition (CVD) offer various advantages over other techniques like purity of thin film, low cost than compared with other vaccum based technology, thin film with different morphology and good adhesion with substrate[13]. Although, sol-gel technique is not suitable to produce $\mathrm{TiO}_{2}$ thin film for solar cell application, they offer other advantages like compositional control, homogeneity and low crystallization temperature [13]. Spray pyrolysis offers advantages like low cost, scalable and uniform deposition on large area substrate. $\mathrm{TiO}_{2}$ thin film in its pure form, without doping has low conductivity that makes them unsuitable for solar cell application where doped $\mathrm{TiO}_{2}$ layer can be used to make them suitable for photovoltaic $[14,15]$. However, practical efficiency is very low for such solar cells due to various defects and improper optimization of parameters. Their various parameters can be optimized using various numerical simulation softwares like PC1D, AFORS-HET [16], silvaco ATLAS [17, 18], TCAD $[19,20]$, AMPS [21], SCAPS 1D [22-24] etc. AFORS-HET is an automat simulation software based on Shockley-read-hall recombination statistics which solves one-dimension semiconductor equation $[7,25$, 26]. This software is used for modelling homojunction and heterojunction devices [25, 27, 28]. This program solves 1-D semiconductor equation which is based on physical differential equation like transport \& continuity equation and poisson's equation [29]. Lambert beer law is used which is based on optical model for estimation of optical parameter [7]. In this work, AFORS-HET automat simulation software is used to simulate $\mathrm{AZO} / \mathrm{Si}$ and $\mathrm{TiO}_{2} / \mathrm{Si}$ heterojunction solar cell and its various parameters like thickness of silicon wafer, thickness of $\mathrm{AZO}$ layer, thickness of $\mathrm{TiO}_{2}$ layer, doping concentration of donors $\left(N_{d}\right)$, effective conduction band density $\left(N_{c}\right)$, and texturing at different angle is optimized [30]. Texturing of silicon wafer at different angle is performed to study the change in behaviour and performance of solar cell with respect to plane heterojunction solar cell [31, 32]. Texturing plays important role for improvement in performance of thin film based silicon heterojunction solar cells due to increment in light trapping of incoming light and multiple internal reflection, which helps to increase charge carrier transport and hence, enhances the overall efficiency of solar cell $[33,34]$. Various literatures are reported for plane and textured (pyramidal and inverted pyramidal) solar cells $[35,36]$. Efficiency is also dependent at various texturing angle and hence, desired texturing angle can be applied to produce maximum power conversion efficiency from solar cell [37]. Using AZO as n-type material, an efficiency of $6.8 \%$ is reported for $\mathrm{Al}: \mathrm{ZnO} / \mathrm{CdS} / \mathrm{CulnSe}_{2}$ polycrystalline solar cell in [10]. $6.8 \%$ efficiency is reported for $\mathrm{Al}: \mathrm{ZnO} / \mathrm{Si}$ heterojunction solar cell in [38]. However, maximum theoretical efficiency of $29.43 \%$ can be achieved for silicon heterojunction in [39-41] respectively. A maximum efficiency of $17 \%$ for ultra-thin n-type AZO layer and $17.5 \%$ for ultra-thin $\mathrm{TiO}_{2}$ as n-type layer is achieved by optimizing its properties which is much higher than practically obtained efficiency signifying a lot of improvements can be performed to improve efficiency of $\mathrm{TiO}_{2} / \mathrm{Si}$ and AZO/Si heterojunction solar cell. 


\section{Simulation Details And Device Structures}

AFORS-HET automat simulation software is used in this work for modelling the $\mathrm{AZO} / \mathrm{Si}$ and $\mathrm{TiO}_{2} / \mathrm{Si}$ heterojunction solar cell where ultra-thin $\mathrm{AZO}$ layer \& $\mathrm{TiO}_{2}$ layer acts as $\mathrm{n}$-type layer and crystalline $\mathrm{p}$-type silicon ( $\mathrm{p}$-cSi) wafer acts as p-type absorber layer. Device structure used for modelling in this work is described in figure 1. All default values present in AFORS-HET software are considered for the modelling $\mathrm{TiO}_{2}$ \& AZO layer based silicon heterojunction (SHJ) solar cells except the parameters used to be optimized. Illuminance of radiation AM 1.5 is used with power density of $100 \mathrm{~mW} / \mathrm{cm}^{2}$ for simulation in present study. Standard values of $\mathrm{Al}: \mathrm{ZnO}, \mathrm{TiO}_{2}$ and $\mathrm{p}$-cSi are taken from references $[7,15,25]$. Flatband schottky front interface and flatband schottky back interface is chosen as default in present study. No interface effect is studied in this article, hence 'No Interface' is considered as default. Front contact boundary and back contact boundary are chosen as constant (zero) i.e. no absorption loss is considered. Carrier lifetime in silicon is considered as $1 \mathrm{msec}$; Diffusion length of carriers in silicon wafer is considered to be around $100 \mu \mathrm{m}$. Resistivity and order of series resistance and shunt resistance of layer has been taken as default values i.e. minimum for series resistance $\left(R_{s}: 0 \mathrm{ohm}\right)$ and max for shunt resistance $\left(R_{\text {shunt }}: 10^{30} \mathrm{ohm}\right)$. In this work, following studies are carried out: (i) thickness optimization of p-cSi layer, (ii) thickness optimization of ultra-thin $\mathrm{AZO}$ and $\mathrm{TiO}_{2}$ layer, (iii) optimization of doping concentration of donors $\left(N_{d}\right)$, (iv) optimization of effective conduction band density $\left(N_{c}\right)$ and $(v)$ optimization of texturing at various angles.

Table 1 Input parameters used for AFORS-HET numerical simulation with p-type crystalline silicon wafer as p-layer and $\mathrm{AZO} \& \mathrm{TiO}_{2}$ as n-layer. 


\begin{tabular}{|lllll|}
\hline Parameter & & p-cSi & AZO & TiO $_{2}$ \\
\hline Thickness & $\mathrm{d}$ & varied $(\mu \mathrm{m})$ & varied $(\mathrm{nm})$ & varied $(\mathrm{nm})$ \\
\hline Dielectric Constant & $\mathrm{dk}$ & 11.9 & 9 & 8.6 \\
\hline Electron Affinity & $\mathrm{eV}$ & 4.05 & 4.4 & 3.9 \\
\hline band gap & $\mathrm{eV}$ & 1.12 & 3.37 & 3 \\
\hline Opt. BG & $\mathrm{eV}$ & 1.12 & 3.3 & 3 \\
\hline Effective CB density & $\mathrm{cm}^{-3}$ & varied & varied & varied \\
\hline Effective VB density & $\mathrm{cm}^{-3}$ & $2.5 \times 10^{19}$ & $1 \times 10^{19}$ & $1 \times 10^{19}$ \\
\hline Electron mobility & $\mathrm{cm}^{2} \mathrm{v}^{-1} \mathrm{~s}^{-1}$ & 1041 & 100 & 20 \\
\hline hole mobility & $\mathrm{cm}^{2} \mathrm{v}^{-1} \mathrm{~s}^{-1}$ & 412.9 & 25 & 10 \\
\hline Acceptor concentration & $\mathrm{cm}^{-3}$ & $1.5 \times 10^{16}$ & 0 & 0 \\
\hline donor concentration & $\mathrm{cm}^{-3}$ & 0 & varied & varied \\
\hline Thermal vel. of e & $\mathrm{cms}^{-1}$ & $1 \times 10^{7}$ & $1 \times 10^{7}$ & $2.99 \times 10^{6}$ \\
\hline Thermal vel. of h & $\mathrm{cms}^{-1}$ & $1 \times 10^{7}$ & $1 \times 10^{7}$ & $6.76 \times 10^{6}$ \\
\hline layer density & $\mathrm{gcm}^{-3}$ & 2.328 & 2.33 & 2.328 \\
\hline
\end{tabular}

Texturing plays important role in enhancing the efficiency of solar cells [33]. Texturing of silicon wafer surface can be performed through chemical etching. Due to textured morphology of layers in solar cells there is re-absorption of reflected rays which helps in minimizing the lost reflected light [12]. Texturing increases excess charge carriers due to light trapping and multiple internal reflection which helps in enhancing overall performance \& conversion efficiency of solar cell. Moreover, efficiency also depends on angle at which texturing is performed to produce an efficient solar cell [42]. There are several reports on pyramidal and inverted pyramidal texturing for silicon solar cells [12,33]. In this article, texturing is performed at various texturing angle and performance of modelled AZO/Si heterojunction solar cell is optimized.

\section{Results And Discussion}

\section{Thickness optimization of p-cSi silicon wafer:}

In this section, thickness of p-type crystalline silicon wafer is optimized. Manufacturing of solar cells using thin p-cSi wafer can be cost effective up to certain extent at industrial scale. Though nowadays ncSi ingots are also reasonable in cost compared to p-cSi and wafer of around $200 \mu \mathrm{m}$ thickness are in 
use at industrial scale. However, through our simulation we have obtained that its thickness can further be reduced to upto $70 \mu \mathrm{m}$ without affecting its performance. All other parameters were in accordance with the values reported in Table-1. Efficiency rapidly increases with thickness initially, begins to saturate after $70 \mu \mathrm{m}$ and remains constant upto $500 \mu \mathrm{m}$. This can be well explained as initially as thickness increases, more number of charge carriers are generated and contribute to flow of charge across $p-n$ junction. However, after certain thickness, charge carriers generated does not travel across junction due to thickening of wafer and less diffusion length of charge carriers in silicon wafer which is around $100 \mu \mathrm{m}$. When thickness of silicon wafer gets thicker than its diffusion length, charger carriers generated does not travel upto $p$-n junction and gets recombined and hence charge carriers generated having diffusion length more than $100 \mu \mathrm{m}$ does not participate in charge collection. Thus, efficiency begins to saturate after 70 $\mu \mathrm{m}$. Also, film gets flexible when its thickness reduces beyond $50 \mu \mathrm{m}$. Experimentally, an ultrathin flexible film of thickness $45 \mu \mathrm{m}$ has been fabricated by [43] using Cu-assisted chemical etching of bulk c-Si producing conversion efficiency of over $17 \%$. Also, mechanical stress, multi flexure, fracture and static test has been conducted by [44] for flexible thin films based crystalline silicon solar cells where thickness of flexible thin film varying from $20 \mu \mathrm{m}$ to $50 \mu \mathrm{m}$. Thus, an ultrathin stable film can be utilized for silicon based HJ solar cells. Hence, the thickness of p-type silicon wafer at $70 \mu \mathrm{m}$ is optimized in this work. Similar pattern is also observed for short circuit current $\left(\mathrm{J}_{\mathrm{Sc}}\right)$ curve. This behaviour is well illustrated in $V_{\text {oc }}$ vs thickness curve figure: 2(a), $J_{s c}$ vs thickness curve figure: 2(b) and fill factor (FF) vs thickness curve figure: 2 (c). $V_{o c}, J_{s c}$ and FF values remains nearly constant from $70 \mu \mathrm{m}$ to $500 \mu \mathrm{m} ; \mathrm{V}_{\mathrm{oc}}$ and $\mathrm{J}_{\mathrm{sc}}$ rapidly decreases on further reducing the thickness of $\mathrm{p}$-cSi layer which accounts for the decrease in efficiency. Fill factor firstly increases slightly and then decreases but this increase is less significant than rapid decrease in $\mathrm{V}_{\mathrm{oc}}$ and $\mathrm{J}_{\mathrm{sc}}$ which results in decrease in efficiency. Hence, the thickness of $\mathrm{p}$-cSi layer is optimized at $70 \mu \mathrm{m}$ to obtain an efficiency of $12.84 \%$ for AZO layer and $12.16 \%$ for $\mathrm{TiO}_{2}$ layer based p-cSi $\mathrm{HJ}$ solar cells.

\section{Thickness optimization of ultra-thin n-type $\mathrm{AZO}$ and $\mathrm{TiO}_{2}$ layer:}

Thickness of $\mathrm{AZO}$ and $\mathrm{TiO}_{2}$ layer is varied from $0.5 \mathrm{~nm}$ to $10 \mathrm{~nm}$ and open circuit voltage $\left(\mathrm{V}_{\text {oc }}\right)$, short circuit current $\left(\mathrm{J}_{\mathrm{sc}}\right)$, fill factor $(\mathrm{FF})$ and efficiency is recorded with respect to thickness of $\mathrm{AZO} \& \mathrm{TiO}_{2}$ layer, Figure 3 (a) to (d) represents curve for each respectively. All other parameters were in accordance with the values reported in Table-1. There is no effect of thickness variation of $\mathrm{TiO}_{2}$ layer on $\mathrm{V}_{\text {oc }}$ and it remains constant at $546.1 \mathrm{mV}$. Same pattern is observed for AZO layer as well, However, there is slight enhancement in $V_{\text {oc }}$ at 3 - $4 \mathrm{~nm}$, giving maximum $V_{\text {oc }}$ of $549.2 \mathrm{mV}$ below $3 \mathrm{~nm}$. Short circuit current linearly decreases with increase in its thickness giving maximum $J_{s c}$ at $0.5 \mathrm{~nm}$. However, due to practical limitations, deposition of layers using modern techniques is limited upto $3 \mathrm{~nm}$ for stable film and hence $J_{s c}$ at $3 \mathrm{~nm}$ giving short circuit current of $29.12 \mathrm{~mA}$ for ultra-thin AZO layer and $29.02 \mathrm{~mA}$ for ultra-thin $\mathrm{TiO}_{2}$ layer based solar cell is considered as optimized short circuit current [7]. This behaviour is expected, since thinning of emitter layer will contribute to flow more number of charge carriers generated in absorber layer and easy transport across layer due to decrease in resistance, thus recombination rate also 
decreases; hence resulting in enhancement of short circuit current with decrease in thickness of emitter layer. Fill factor also decreases linearly with increasing thickness. This can be attributed due to decrease of series resistance as we decrease its thickness. Hence, overall efficiency increases linearly with decreasing thickness and gives maximum efficiency of $12.84 \%$ for ultra-thin $n$-type AZO layer and $12.59 \%$ for ultra-thin $\mathrm{n}$-type $\mathrm{TiO}_{2}$ layer based $\mathrm{HJ}$ solar cell.

\section{Doping concentration of donors $\left(\mathrm{N}_{\mathrm{d}}\right)$}

Doping of donor concentration plays an important role in enhancing the charge carriers which resulted in improved efficiency. Figure 4 (a) to (d) represents the variation of $\mathrm{V}_{\mathrm{oc}}, \mathrm{J}_{\mathrm{Sc}}, \mathrm{FF}$ and efficiency curve with respect to doping concentration of donors respectively, where $N_{d}$ is varied from $10^{14} \mathrm{~cm}^{-3}$ to $10^{18} \mathrm{~cm}^{-3}$. Doping can be achieved in order of $10^{20} \mathrm{~cm}^{-3}$ using various techniques like ion implantation, mixed molecular monolayer doping technique etc. [45]. Introduction of doping concentration of donors doesn't affect open circuit voltage $\left(\mathrm{V}_{\mathrm{oc}}\right)$ much and it nearly remains constant for both, $\mathrm{AZO}$ and $\mathrm{TiO}_{2}$ layer excluding for $\mathrm{TiO}_{2}$ at lower concentration. Short circuit current $\left(\mathrm{J}_{\mathrm{sc}}\right)$ effectively decreases with increase of doping concentration of donors, giving maximum short circuit current of $30.1 \mathrm{~mA}$ and $30.3 \mathrm{~mA}$ for AZO and $\mathrm{TiO}_{2}$ layer respectively. Maximum fill factor at $10^{15} \mathrm{~cm}^{-3}$ for $\mathrm{TiO}_{2}$ layer and at $10^{16} \mathrm{~cm}^{-3}$ for AZO layer is observed and it nearly remains unaffected on further increasing doping of donors. Similar pattern is followed in efficiency curve as well, where maximum efficiency of $13.13 \%$ for AZO layer and $13.21 \%$ for $\mathrm{TiO}_{2}$ is reported at doping concentration of $1 \times 10^{15} \mathrm{~cm}^{-3}$ and $1 \times 10^{14} \mathrm{~cm}^{-3}$ respectively. Performance of device degrades as doping concentration increases beyond order of $10^{15}$ which can be due to introduction of defect states in $\mathrm{AZO}$ and $\mathrm{TiO}_{2}$ layer at higher doping concentration limiting its performance. With increase in defect states in space charge region, it can create conduction channel across it and leakage current starts flowing which degrades the performance of device. Hence, efficiency decreases with further increase of doping concentration for AZO layer beyond $10^{15} \mathrm{~cm}^{-3}$. Similar pattern is followed for $\mathrm{TiO}_{2}$ layer as well, where efficiency remains nearly constant upto $10^{15} \mathrm{~cm}^{-3}$ and decreases thereafter due to introduction of defect states at higher concentration.

\section{Effective conduction band density}

During carrier charge transport, effective conduction band density and effective valence band density are the major density of states that plays important role during charge transport. Figure 5.1 to 5.4 represents the variation of $\mathrm{V}_{\mathrm{oc}}, \mathrm{J}_{\mathrm{Sc}}, \mathrm{FF}$ and efficiency curve with respect to effective conduction band density respectively. All other parameters were in accordance with the values reported in Table-1. Effective conduction band density is varied from $10^{15} \mathrm{~cm}^{-3}$ to $10^{19} \mathrm{~cm}^{-3}$ as shown in figure 5 (a) to 5 (d). Similar variation in tail density of states from $10^{13} \mathrm{~cm}^{-3}$ to $10^{21} \mathrm{~cm}^{-3}$ has been reported in [46]. Open circuit voltage remains constant on varying conduction band density for both, $\mathrm{AZO} \& \mathrm{TiO}_{2}$ layer. Short circuit current linearly decreases slightly on increasing $\mathrm{N}_{\mathrm{c}}$ giving maximum $\mathrm{J}_{\mathrm{sc}}$ of $30.4 \mathrm{~mA}$ at $10^{15} \mathrm{~cm}^{-3}$ for $\mathrm{TiO}_{2}$ layer and $30.08 \mathrm{~mA}$ at $10^{19} \mathrm{~cm}^{-3}$ for AZO layer based solar cell. Fill factor is significantly influenced with 
$\mathrm{N}_{\mathrm{c}}$ and thus contributes more to efficiency. Hence, efficiency follows the pattern like fill factor. Efficiency increases initially exhibiting best efficiency at around $10^{16} \mathrm{~cm}^{-3}$ and remains nearly constant thereafter which can be attributed to increase in shunt resistance and decrease in series resistance initially thus affecting fill factor of device accordingly. After certain level, there is no significant change in shunt resistance and series resistance with change in effective conduction band density resulting in nearly constant fill factor, thus efficiency also gets saturated. However, initial increase in efficiency is more significant in case of $\mathrm{TiO}_{2}$ based solar cell than compare to AZO based silicon solar cell and further study needs to be carried out for more fundamental reason behind this. Maximum efficiency of $13.24 \%$ for AZO layer and $13.21 \%$ for $\mathrm{TiO}_{2}$ layer at $5 \times 10^{15} \mathrm{~cm}^{-3}$ and $1 \times 10^{17} \mathrm{~cm}^{-3}$ respectively is obtained for $\mathrm{AZO} / \mathrm{Si}$ and $\mathrm{TiO}_{2} / \mathrm{Si}$ based $\mathrm{HJ}$ solar cells respectively.

\section{Texturing angle}

Efficiency of solar cell can be significantly enhanced through texturing [35]. Many reports are there on pyramidal and inverted pyramid textured silicon wafer solar cell. Texturing angle is varied from $0^{\circ}$ to $89^{\circ}$ as shown in figure $6 . \mathrm{V}_{\text {oc }}$ increases linearly with texturing angle giving maximum open circuit voltage $555.5 \mathrm{mV}$ at $89^{\circ}$ for both, AZO layer based and $\mathrm{TiO}_{2}$ layer based silicon $\mathrm{HJ}$ solar cells. Similar trend is followed in $\mathrm{J}_{\mathrm{sc}}$ curve giving maximum short circuit current of $37.81 \mathrm{~mA}$ and $38.92 \mathrm{~mA}$ at $89^{\circ}$ for AZO layer based and $\mathrm{TiO}_{2}$ layer based silicon $\mathrm{HJ}$ solar cells. Fill factor nearly remains constant and varies from $80.25 \%$ to $80.96 \%$ for entire range of texturing angle. Efficiency follows the same curve, giving maximum efficiency of $17 \%$ for $\mathrm{AZO}$ layer and $17.5 \%$ for $\mathrm{TiO}_{2}$ layer at texturing angle of $89^{\circ}$. Efficiency increases linearly with texturing angle due to increment in close packing density of textured surface which increases the internal multiple reflection of illuminated light and helps to enhance absorption loss, thus contributes in collecting more charge carriers [42]. Thus efficiency of modelled AZO/Si HJ solar cell is significantly increased. Hence all the parameters of $\mathrm{TiO}_{2}, \mathrm{AZO}$ layer and p-cSi wafer layer is optimized to attain maximum efficiency of $17 \%$ for $\mathrm{AZO} / \mathrm{Si}$ and $17.5 \%$ for $\mathrm{TiO}_{2} / \mathrm{p}$-cSi heterojunction solar cells.

\section{Conclusion}

Numerical simulation is performed using AFORS-HET software program to achieve a maximum efficiency of $17 \%$ and $17.5 \%$ for ultra-thin n-type $\mathrm{AZO}$ and $\mathrm{TiO}_{2}$ layer based silicon $\mathrm{HJ}$ solar cell by optimizing its various parameters. In this work, thickness of p-cSi wafer is optimized at $70 \mu \mathrm{m}$ to obtain an efficiency of $12.84 \%$ for ultra-thin $\mathrm{AZO}$ layer and $12.16 \%$ for ultra-thin $\mathrm{TiO}_{2}$ layer based $\mathrm{p}$-cSi $\mathrm{HJ}$ solar cells respectively. It is followed by optimizing thickness of ultra-thin $\mathrm{TiO}_{2}$ and $\mathrm{AZO}$ layer at $3 \mathrm{~nm}$ to obtain an efficiency of $12.84 \%$ for $\mathrm{AZO}$ layer and $12.59 \%$ for $\mathrm{TiO}_{2}$ layer based $\mathrm{HJ}$ solar cell respectively. Doping concentration of donors $\left(\mathrm{N}_{\mathrm{d}}\right)$ is optimized at $1 \times 10^{15} \mathrm{~cm}^{-3}$ for ultra-thin AZO layer and $1 \times 10^{14} \mathrm{~cm}^{-3}$ for ultra-thin $\mathrm{TiO}_{2}$ layer to obtain efficiency of $13.13 \%$ and $13.21 \%$ for $\mathrm{AZO} / \mathrm{Si}$ and $\mathrm{TiO}_{2} / \mathrm{Si} \mathrm{HJ}$ solar cells respectively. 
Effective conduction band density is optimized at $5 \times 10^{15} \mathrm{~cm}^{-3}$ for AZO layer and at $1 \times 10^{17} \mathrm{~cm}^{-3}$ for $\mathrm{TiO}_{2}$ layer based solar cell and obtained an efficiency of $13.24 \%$ and $13.21 \%$ respectively. Finally, the role of surface texturing at various angle is studied and reported the maximum efficiency of $17 \%$ and $17.5 \%$ for $\mathrm{AZO}$ and $\mathrm{TiO}_{2}$ layer based silicon $\mathrm{HJ}$ solar cells respectively. Linear increase in efficiency with respect to texturing angle is observed, where efficiency of $14.21 \%$ for AZO layer and $14.45 \%$ for $\mathrm{TiO}_{2}$ layer based silicon HJ solar cells for pyramidal surface texturing is obtained. Thickness optimization of $\mathrm{p}$-cSi at 70 $\mu \mathrm{m}$ and removal of intrinsic amorphous silicon layer can be very cost effective for manufacturing AZO/Si heterojunction solar cells at industrial scale for commercial production; as deposition of i-layer a-Si and other similar based $\mathrm{HJ}$ solar cells with intrinsic layer involves additional processing setup. Processing of such layers also has some serious environmental \& safety issues. Optimization of texturing angle plays a significant role in enhancing the efficiency above $17 \%$ for the above modelled $\mathrm{HJ}$ solar cell. Hence, efficiency reported using $\mathrm{AZO}$ and $\mathrm{TiO}_{2}$ layer based silicon heterojunction solar cell in this article can be cost effective and efficient solar cell. Such results are encouraging and exciting for practical applications. However, practically it is challenging to texture the silicon wafer at such angle with high accuracy. Lasers can be used to texture silicon surface at such specific angles though such process may cost more. Further investigation on above modelled cell can be performed by introducing intrinsic thin layer, $\mathrm{p}+$ layer, $\mathrm{n}+$ layer and BSF layer to simulate HIT, HITBSF and HIT-BIFACIAL solar cells to further improve the efficiency of solar cell.

\section{Declarations}

\section{Acknowledgement:}

Authors are grateful to Director, National Physical Laboratory, New Delhi India for his kind support. Author, Chandan Yadav is thankful to Council of Scientific and Industrial Research (CSIR), Govt. of India for providing Junior Research Fellowship (JRF, 31/001(0627)/2020-EMR-1). Authors also acknowledge Helmholtz-Zentrum Berlin for providing AFORS-HET simulation software.

Funding Statement: The research leading to these results received funding from Council of Scientific and Industrial Research (CSIR), Govt. of India, for providing JRF under grant no. 31/001(0627)/2020-EMR-1 to author Chandan Yadav.

\section{Authors Contribution:}

Chandan Yadav: Writing original draft, simulation work. Sushil Kumar: Conceptualization, review \& editing, supervision.

\section{Compliance with Ethical Standards:}

Conflict of Interest: Authors declare no conflict of interest that are directly or indirectly related to the work submitted for publication. 
Research Involving human participants or animals: Not applicable.

Informed Consent: Not applicable.

Consent to participate: Not applicable.

Consent for publication: Not applicable.

Data availability statement: This paper does not use any raw or processed data. It includes all the data necessary to perform the calculations and supports the findings of this study.

\section{References}

1. Dwivedi N, Kumar S, Singh S, Malik HK (2012) Oxygen modified diamond-like carbon as window layer for amorphous silicon solar cells. Sol Energy 86:220-230. https://doi.org/10.1016/j.solener.2011.09.025

2. Nordseth $\varnothing$, Kumar R, Bergum K, et al (2018) Metal oxide thin-film heterojunctions for photovoltaic applications. Materials (Basel) 11:1-10. https://doi.org/10.3390/ma11122593

3. G.J.H.M van Sark W, Korte L, Roca F (2013) Physics \& Technology of Amorphous-Crystalline Heterostructure Silicon Solar Cells

4. Tsunomura $Y$, Yoshimine $Y$, Taguchi M, et al (2009) Twenty-two percent efficiency HIT solar cell. Sol Energy Mater Sol Cells 93:670-673. https://doi.org/10.1016/j.solmat.2008.02.037

5. Kumar S, Dwivedi N, Rauthan CMS, Panwar OS (2010) Properties of nitrogen diluted hydrogenated amorphous carbon (n-type a-C:H) films and their realization in n-type a-C:H/p-type crystalline silicon heterojunction diodes. Vacuum 84:882-889. https://doi.org/10.1016/j.vacuum.2009.12.003

6. Ore E, Amaratunga G (2020) Crystalline Silicon Heterojunction Solar Cells With Metal Oxide Window Layers. 1139-1142. https://doi.org/10.1109/pvsc40753.2019.8981326

7. Dwivedi N, Kumar S, Bisht A, et al (2013) Simulation approach for optimization of device structure and thickness of HIT solar cells to achieve $\sim 27 \%$ efficiency. Sol Energy 88:31-41. https://doi.org/10.1016/j.solener.2012.11.008

8. Bivour M, Temmler J, Steinkemper H, Hermle M (2015) Molybdenum and tungsten oxide: High work function wide band gap contact materials for hole selective contacts of silicon solar cells. Sol Energy Mater Sol Cells 142:34-41. https://doi.org/10.1016/j.solmat.2015.05.031

9. Toufik Z, Hamza L, Mohamed F (2016) Study and Simulation of the Heterojunction Thin Film Solar Cell a-Si ( n )/ a-Si (i )/ c-Si ( p )/ a-Si ( i )/ a-Si ( p ). J Electron Mater 45:3943-3948. https://doi.org/10.1007/s11664-016-4542-1

10. Martínez MA, Herrero J, Gutiérrez MT (1997) Deposition of transparent and conductive Al-doped ZnO thin films for photovoltaic solar cells. Sol Energy Mater Sol Cells 45:75-86. https://doi.org/10.1016/S0927-0248(96)00066-9 
11. Selmane N, Cheknane ALI, Hilal HS (2020) Optimization of Al-Doped ZnO Transparent Conducting Oxide and Emitter Layers for Enhanced Performance of Si Heterojunction Solar Cells. J Electron Mater 49:2179-2190. https://doi.org/10.1007/s11664-019-07917-w

12. Sharma M, Chaudhary D, Dwivedi N, et al (2017) Simulating the Role of TCO Materials, their Surface Texturing and Band Gap of Amorphous Silicon Layers on the Efficiency of Amorphous Silicon Thin Film Solar Cells. Silicon 9:59-68. https://doi.org/10.1007/s12633-015-9331-6

13. Anitha VC, Banerjee AN, Joo SW (2015) Recent developments in TiO2 as n- and p-type transparent semiconductors: synthesis, modification, properties, and energy-related applications. J Mater Sci 50:7495-7536. https://doi.org/10.1007/s10853-015-9303-7

14. Mehmood H, Nasser $H$, Tauqeer T, Turan R (2019) Simulation of silicon heterostructure solar cell featuring dopant-free carrier-selective molybdenum oxide and titanium oxide contacts. Renew Energy 143:359-367. https://doi.org/10.1016/j.renene.2019.05.007

15. Wang T, Wang P, Ding K, Liang Q (2019) Numerical simulation of carrier transporting layer free planar perovskite cells. Optik (Stuttg) 179:1019-1026. https://doi.org/10.1016/j.ijleo.2018.11.050

16. Park H, Kim D, Cho EC, et al (2020) Effect on the reduction of the barrier height in rear-emitter silicon heterojunction solar cells using Ar plasma-treated ITO film. Curr Appl Phys 20:219-225. https://doi.org/10.1016/j.cap.2019.09.009

17. Chala S, Sengouga N, Yakuphanoglu $F$ (2015) Modeling the effect of defects on the performance of an n-CdO/p-Si solar cell. Vacuum 120:81-88. https://doi.org/10.1016/j.vacuum.2015.05.019

18. Pandey R, Chaujar R (2016) Numerical simulation of rear contact silicon solar cell with a novel front surface design for the suppression of interface recombination and improved absorption. Curr Appl Phys 16:1581-1587. https://doi.org/10.1016/j.cap.2016.09.002

19. Li Q, Tao K, Sun Y, et al (2016) Two dimensional simulation studies on amorphous silicon stack as front surface field for interdigitated back contact solar cells. Vacuum 125:56-64. https://doi.org/10.1016/j.vacuum.2015.12.007

20. Boukortt NEI, Patanè S, Bouhjar F (2020) Design, Optimization and Characterisation of IBC c-Si (n) Solar Cell. Silicon 12:365-372. https://doi.org/10.1007/s12633-019-00136-2

21. Karimi E, Mohamad S, Ghorashi B (2020) The Effect of SnO 2 and ZnO on the Performance of Perovskite Solar Cells. J Electron Mater 49:364-376. https://doi.org/10.1007/s11664-019-07804-4

22. Huang $\mathrm{CH}$, Chuang WJ (2015) Dependence of performance parameters of CdTe solar cells on semiconductor properties studied by using SCAPS-1D. Vacuum 118:32-37. https://doi.org/10.1016/j.vacuum.2015.03.008

23. Pandey R, Saini AP, Chaujar R (2019) Numerical simulations: Toward the design of $18.6 \%$ efficient and stable perovskite solar cell using reduced cerium oxide based ETL. Vacuum 159:173-181. https://doi.org/10.1016/j.vacuum.2018.10.033

24. Zheng X, Li W, Aberle AG, Venkataraj S (2016) Efficiency enhancement of ultra-thin $\mathrm{Cu}(\mathrm{In}, \mathrm{Ga}) \mathrm{Se} 2$ solar cells: optimizing the absorber bandgap profile by numerical device simulations. Curr Appl Phys 16:1334-1341. https://doi.org/10.1016/j.cap.2016.07.002

Page $11 / 20$ 
25. Rawat A, Sharma M, Chaudhary D, et al (2014) Numerical simulations for high efficiency HIT solar cells using microcrystalline silicon as emitter and back surface field (BSF) layers. Sol Energy 110:691-703. https://doi.org/10.1016/j.solener.2014.10.004

26. Dao VA, Heo J, Choi H, et al (2010) Simulation and study of the influence of the buffer intrinsic layer, back-surface field, densities of interface defects, resistivity of p-type silicon substrate and transparent conductive oxide on heterojunction with intrinsic thin-layer (HIT) solar cell. Sol Energy 84:777-783. https://doi.org/10.1016/j.solener.2010.01.029

27. Sharma M, Kumar S, Dwivedi N, et al (2013) Optimization of band gap, thickness and carrier concentrations for the development of efficient microcrystalline silicon solar cells: A theoretical approach. Sol Energy 97:176-185. https://doi.org/10.1016/j.solener.2013.08.012

28. Lee S, Tark SJ, Kim CS, et al (2013) Influence of front contact work function on silicon heterojunction solar cell performance. Curr Appl Phys 13:836-840. https://doi.org/10.1016/j.cap.2012.12.013

29. Singh S, Kumar S, Dwivedi N (2012) Band gap optimization of p-i-n layers of a-Si:H by computer aided simulation for development of efficient solar cell. Sol Energy 86:1470-1476. https://doi.org/10.1016/j.solener.2012.02.007

30. Khoshsirat N, Yunus NA (2016) Numerical Analysis of In 2 S 3 Layer Thickness , Band Gap and Doping Density for Effective Performance of a CIGS Solar Cell Using SCAPS. J Electron Mater 45:5721-5727. https://doi.org/10.1007/s11664-016-4744-6

31. Angermann $\mathrm{H}$ (2002) Characterization of wet-chemically treated silicon interfaces by surface photovoltage measurements. Anal Bioanal Chem 374:676-680. https://doi.org/10.1007/s00216002-1450-4

32. Angermann $\mathrm{H}$, Rappich $\mathrm{J}$, Korte $\mathrm{L}$, et al (2008) Wet-chemical passivation of atomically flat and structured silicon substrates for solar cell application. Appl Surf Sci 254:3615-3625. https://doi.org/10.1016/j.apsusc.2007.10.099

33. Sivasubramaniam S, Alkaisi MM (2014) Inverted nanopyramid texturing for silicon solar cells using interference lithography. Microelectron Eng 119:146-150.

https://doi.org/10.1016/j.mee.2014.04.004

34. Müller J, Rech B, Springer J, Vanecek M (2004) TCO and light trapping in silicon thin film solar cells. Sol Energy 77:917-930. https://doi.org/10.1016/j.solener.2004.03.015

35. Iftiquar SM, Riaz SN, Mahapatra S (2020) Simulation of Growth of Silicon Thin Films on Textured and Non-textured Surface: A Comparative Study. Silicon. https://doi.org/10.1007/s12633-020-00624w

36. Campbell P, Green MA (1987) Light trapping properties of pyramidally textured surfaces. J Appl Phys 62:243-249. https://doi.org/10.1063/1.339189

37. Gagandeep G, Singh M, Kumar R, Singh V (2019) Graphene as charge transport layers in lead free perovskite solar cell. Mater Res Express 6:. https://doi.org/10.1088/2053-1591/ab4b02

38. Lupan O, Shishiyanu S, Ursaki V, et al (2009) Synthesis of nanostructured Al-doped zinc oxide films on Si for solar cells applications. Sol Energy Mater Sol Cells 93:1417-1422. 
https://doi.org/10.1016/j.solmat.2009.03.012

39. Kerr MJ, Cuevas A, Campbell P (2003) Limiting efficiency of crystalline silicon solar cells due to Coulomb-enhanced Auger recombination. Prog Photovoltaics Res Appl 11:97-104. https://doi.org/10.1002/pip.464

40. Yoshikawa K, Kawasaki H, Yoshida W, et al (2017) Silicon heterojunction solar cell with interdigitated back contacts for a photoconversion efficiency over $26 \%$. Nat Energy 2 :.

https://doi.org/10.1038/nenergy.2017.32

41. Richter A, Hermle M, Glunz SW (2013) Reassessment of the limiting efficiency for crystalline silicon solar cells. IEEE J Photovoltaics 3:1184-1191. https://doi.org/10.1109/JPHOTOV.2013.2270351

42. Hua XS, Zhang YJ, Wang HW (2010) The effect of texture unit shape on silicon surface on the absorption properties. Sol Energy Mater Sol Cells 94:258-262. https://doi.org/10.1016/j.solmat.2009.09.011

43. Tang Q, Shen H, Yao H, et al (2018) Cu-assisted chemical etching of bulk c -Si : A rapid and novel method to obtain $45 \mu \mathrm{m}$ ultrathin fl exible $\mathrm{c}$-Si solar cells with asymmetric front and back light trapping structures. Sol Energy 170:263-272. https://doi.org/10.1016/j.solener.2018.05.072

44. Blakers AWÃ, Armour T (2009) Solar Energy Materials \& Solar Cells Flexible silicon solar cells. Sol Energy Mater Sol Cells 93:1440-1443. https://doi.org/10.1016/j.solmat.2009.03.016

45. Wiel WG Van Der, Huskens J (2015) Controlling the Dopant Dose in Silicon by Mixed-Monolayer Doping. https://doi.org/10.1021/am5079368

46. Chala S, Sengouga N, Yakuphanoğlu F, et al (2018) Extraction of ZnO thin film parameters for modeling a ZnO/Si solar cell. Energy 164:871-880. https://doi.org/10.1016/j.energy.2018.09.035

\section{Tables}

Table 1 Input parameters used for AFORS-HET numerical simulation with p-type crystalline silicon wafer as player and $\mathrm{AZO} \& \mathrm{TiO}_{2}$ as n-layer. 


\begin{tabular}{|ccccc|}
\hline $\begin{array}{c}\text { Parameter } \\
\text { Thickness }\end{array}$ & $\mathrm{d}$ & $\begin{array}{c}\mathrm{p}-\mathrm{cSi} \\
\text { varied }(\mu \mathrm{m})\end{array}$ & $\begin{array}{c}\mathrm{AZO} \\
\text { varied }(\mathrm{nm})\end{array}$ & $\begin{array}{c}\mathrm{TiO}_{2} \\
\text { varied }(\mathrm{nm})\end{array}$ \\
Dielectric Constant & $\mathrm{dk}$ & 11.9 & 9 & 8.6 \\
Electron Affinity & $\mathrm{eV}$ & 4.05 & 4.4 & 3.9 \\
band gap & $\mathrm{eV}$ & 1.12 & 3.37 & 3 \\
Opt. BG & $\mathrm{eV}$ & 1.12 & 3.3 & 3 \\
Effective CB density & $\mathrm{cm}^{-3}$ & varied & varied & varied \\
Effective VB density & $\mathrm{cm}^{-3}$ & $2.5 \times 10^{19}$ & $1 \times 10^{19}$ & $1 \times 10^{19}$ \\
Electron mobility & $\mathrm{cm}^{2} \mathrm{v}^{-1} \mathrm{~s}^{-1}$ & 1041 & 100 & 20 \\
hole mobility & $\mathrm{cm}^{2} \mathrm{v}^{-1} \mathrm{~s}^{-1}$ & 412.9 & 25 & 10 \\
Acceptor concentration & $\mathrm{cm}^{-3}$ & $1.5 \times 10^{16}$ & 0 & 0 \\
donor concentration & $\mathrm{cm}^{-3}$ & 0 & varied & varied \\
Thermal vel. of e & $\mathrm{cms}^{-1}$ & $1 \times 10^{7}$ & $1 \times 10^{7}$ & $2.99 \times 10^{6}$ \\
Thermal vel. of $\mathrm{h}$ & $\mathrm{cms}^{-1}$ & $1 \times 10^{7}$ & $1 \times 10^{7}$ & $6.76 \times 10^{6}$ \\
layer density & $\mathrm{gcm}^{-3}$ & 2.328 & 2.33 & 2.328 \\
\hline
\end{tabular}

\section{Figures}




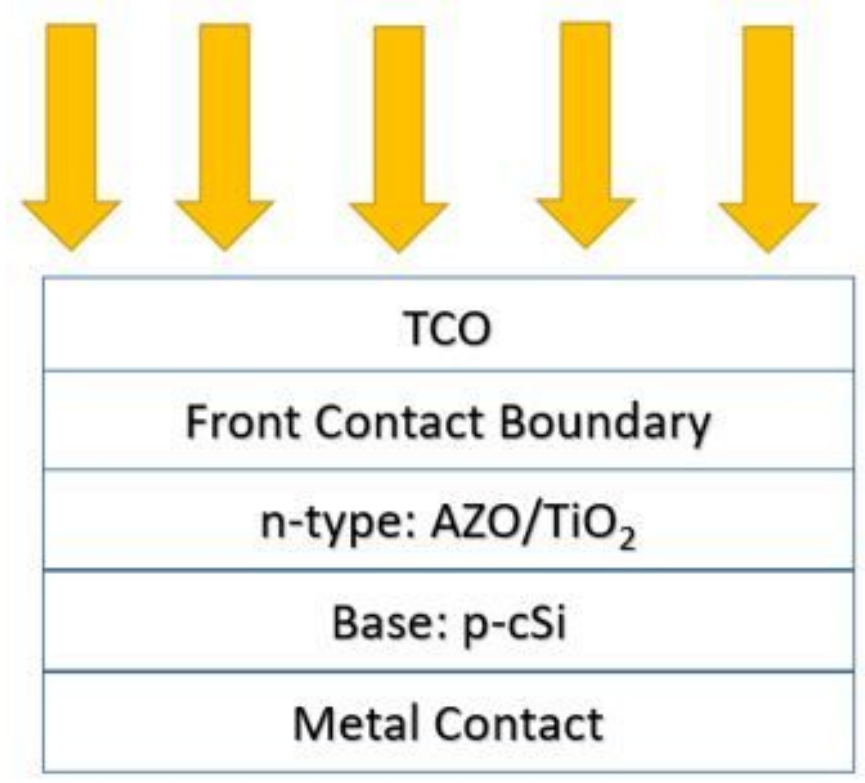

(a)

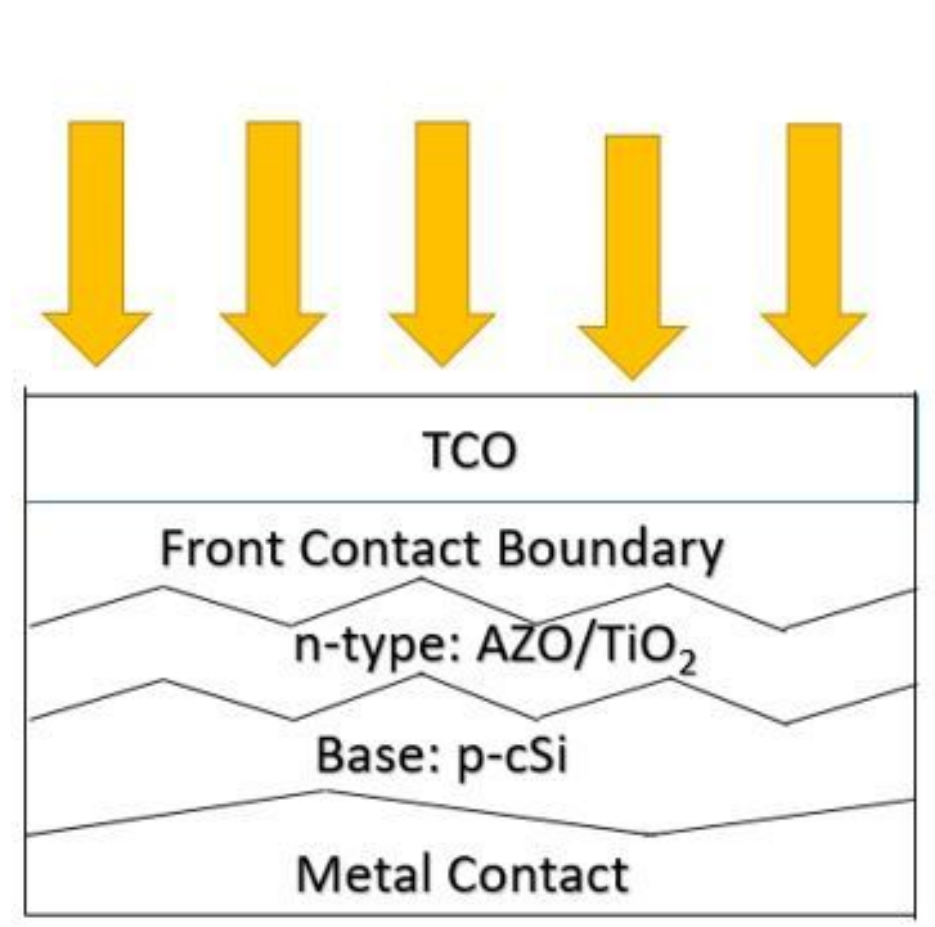

(b)

Figure 1

represents the designed structure for planar and textured AZO/Si HJ and TiO2/Si HJ Solar cells used in numerical simulation with different layer where fig (a) represents planar AZO/Si HJ and TiO2/Si HJ solar cells and fig (b) represents textured AZO/Si HJ and TiO2/Si HJ solar cells. 


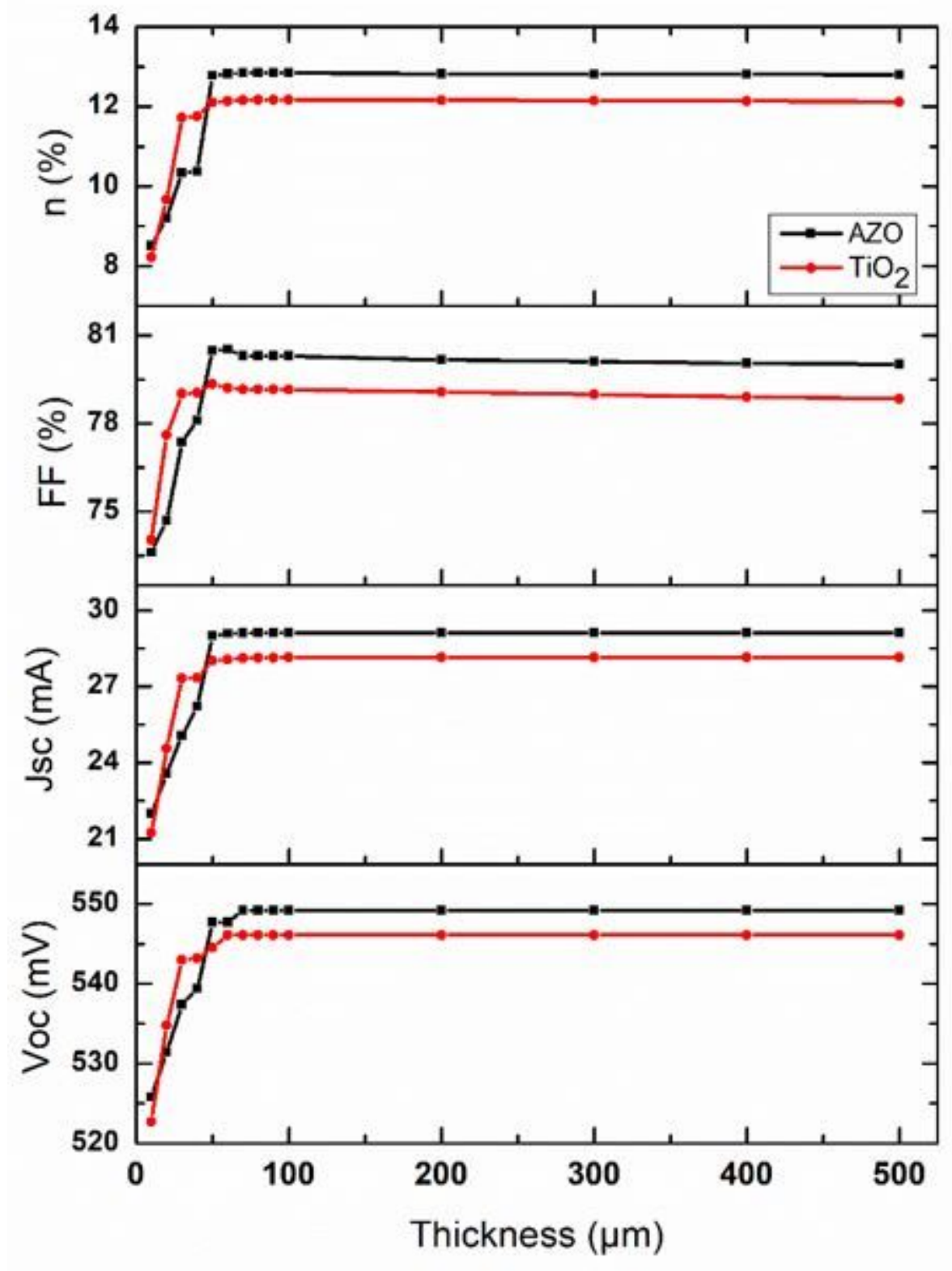

Figure 2

The performance of modelled $\mathrm{AZO}$ and $\mathrm{TiO} 2$ based silicon $\mathrm{HJ}$ solar cell with variation in thickness of $\mathrm{p}$ cSi wafer where Fig (a) - (d) represents Voc, Jsc, FF and $\eta$ vs thickness of p-cSi wafer 


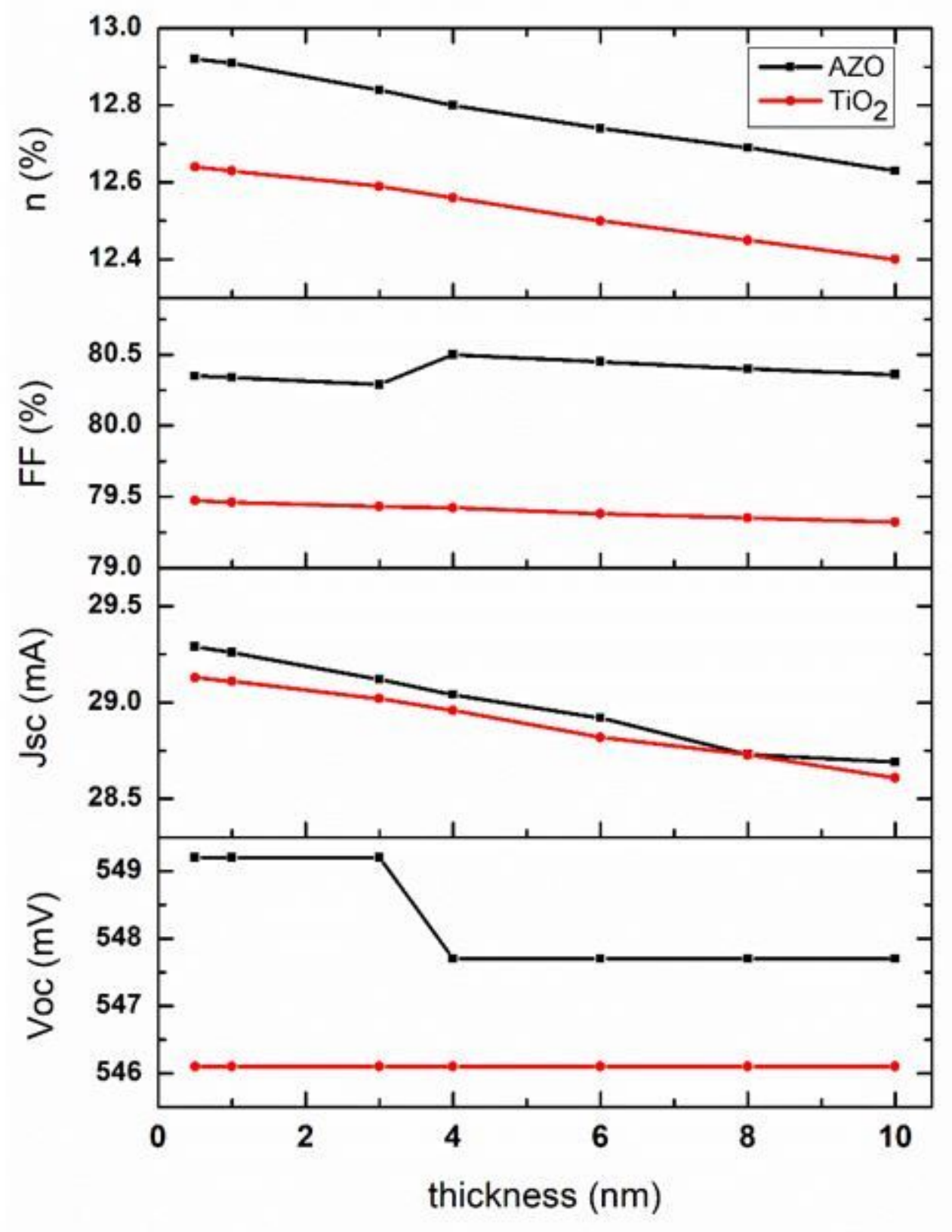

Figure 3

The performance of modelled solar cell with variation in thickness of AZO and TiO2 layer where Fig (a) (d) represents Voc, Jsc, FF and $\eta$ respectively w.r.t. thickness of emitter layer. 


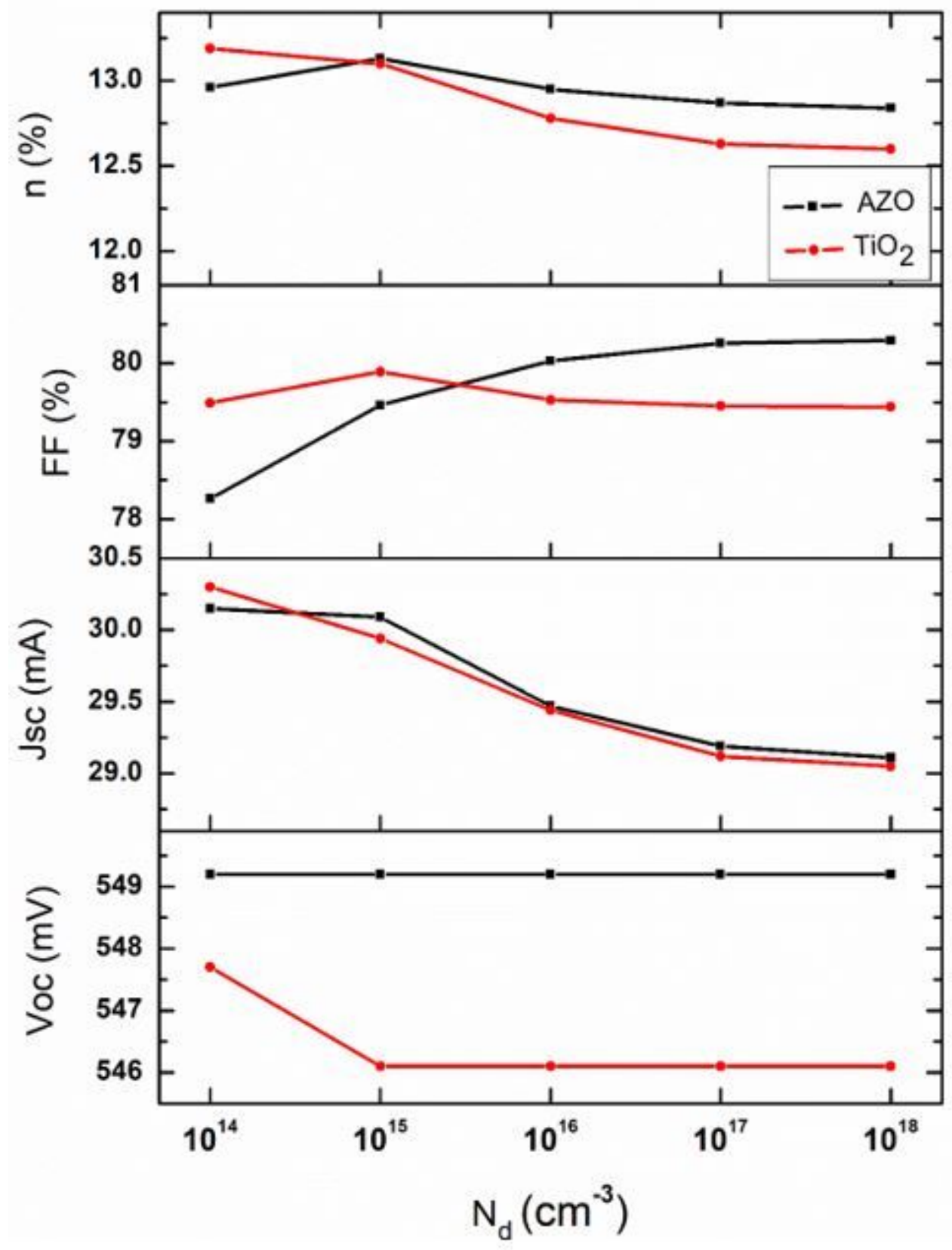

Figure 4

The performance of modelled solar cell with variation in doping concentration of donors (Nd) where Fig 4 (a) - (d) represents the Voc, Jsc, FF and $\eta$ respectively of solar cell with respect to doping concentration of donors $(\mathrm{Nd})$ 


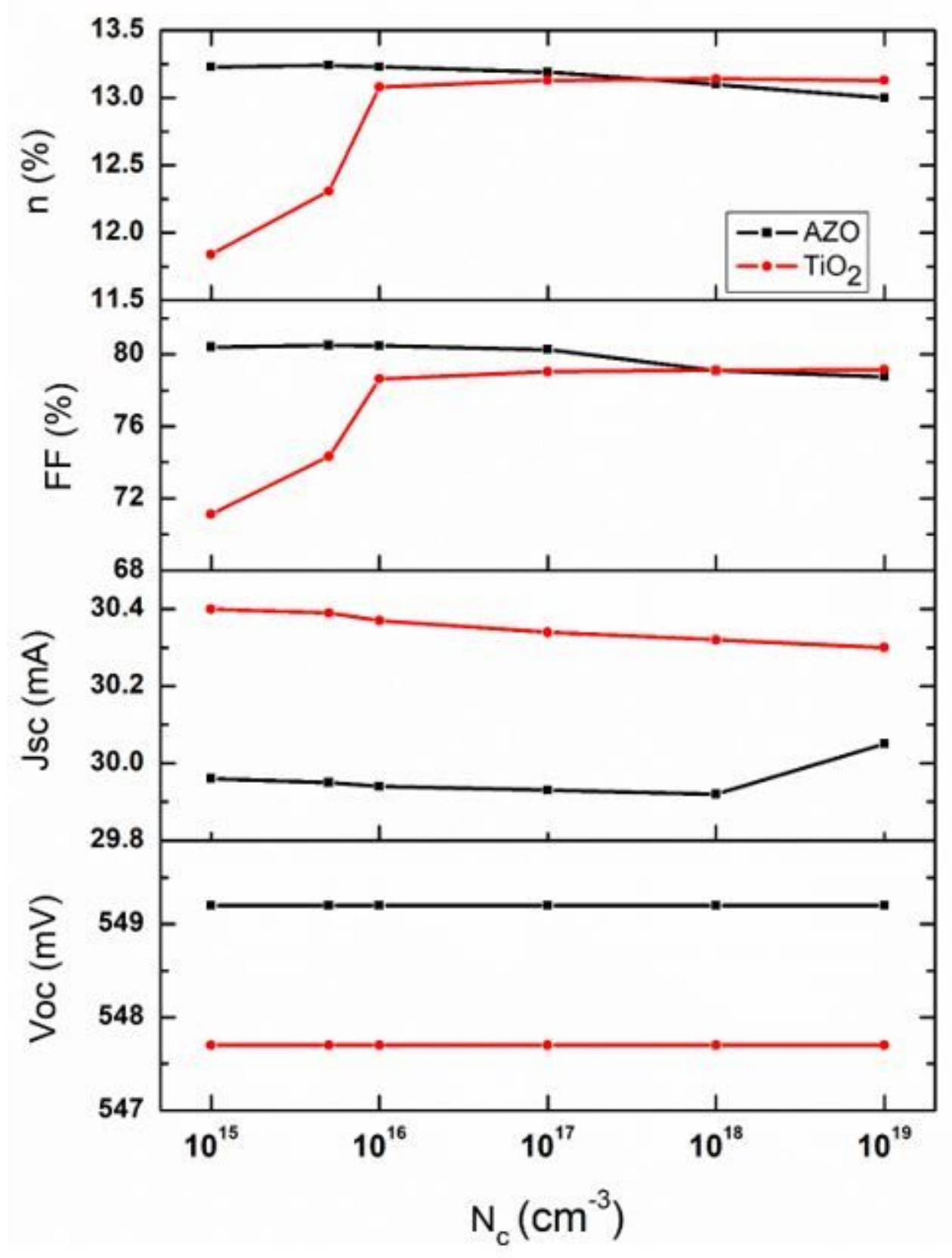

Figure 5

The performance of modelled solar cell with variation in effective conduction band density (Nc). Fig 5(a) - 5(d) represents the Voc, Jsc, FF and $\eta$ respectively of solar cell with respect to effective conduction band density (Nc) 


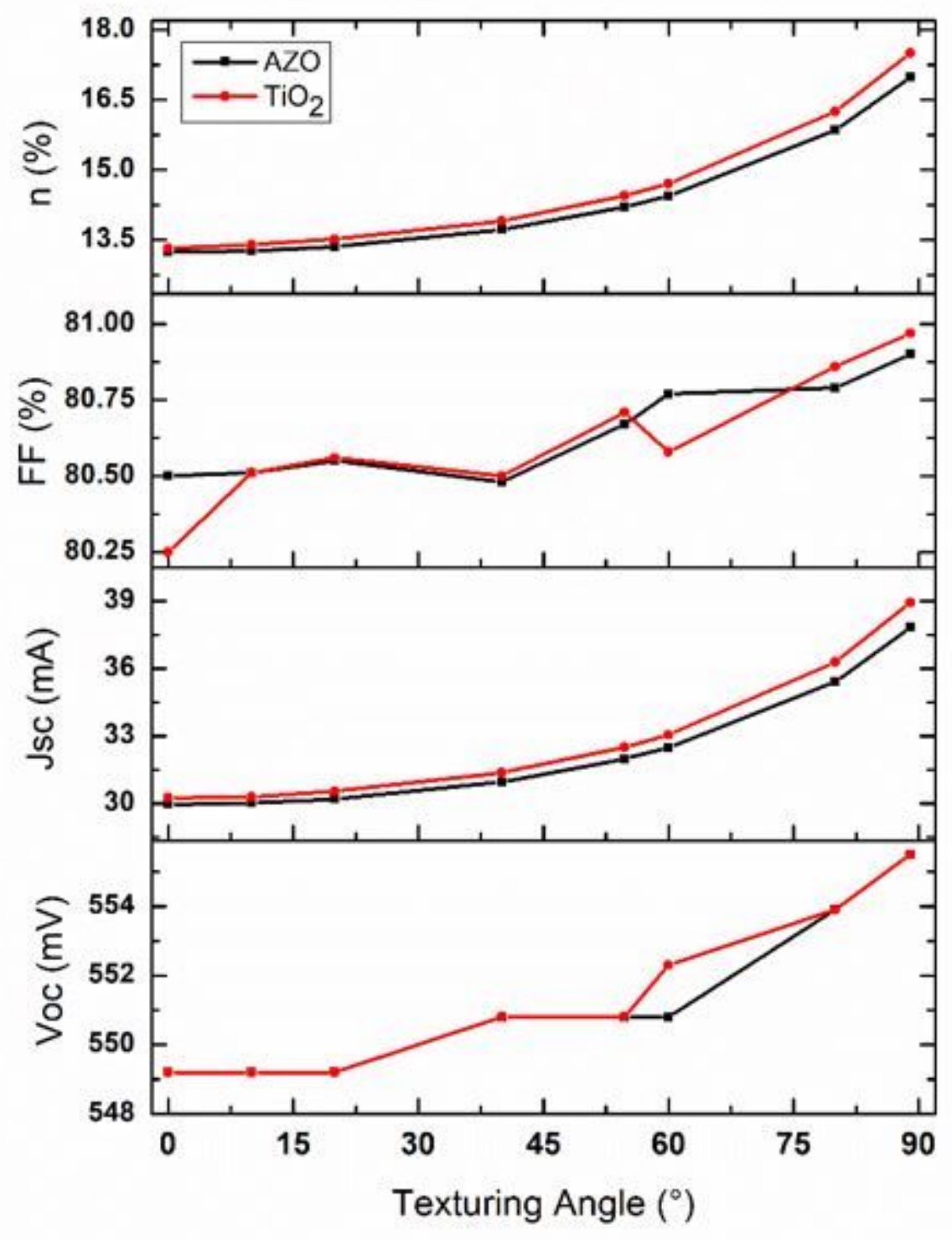

Figure 6

The performance of modelled solar cell with variation in texturing angle where Fig 6 (a) - (d) represents the Voc, Jsc, FF and $\eta$ respectively with respect to texturing angle.

\section{Supplementary Files}

This is a list of supplementary files associated with this preprint. Click to download.

- CoverLetter.docx 